\title{
PEMANFAATAN TEKNOLOGI INFORMASI UNTUK SISTEM INFORMASI MANAJEMEN SEKOLAH: STUDI KASUS PADA SMA 78 JAKARTA
}

\author{
Ayuliana; Neva; Novia Susanti; Fahreza
}

\author{
Computer Science Department, School of Computer Science Binus University \\ Jl. K.H. Syahdan No. 9, Palmerah, Jakarta Barat 11480 \\ ayuliana_st@binus.ac.id; nevnev90@gmail.com; novia_susanti89@yahoo.com; fachreza01@yahoo.com
}

\begin{abstract}
Databases to manage data related to student and school are required to support the implemented information technology applications. This study aims to analyze and design a database system that supports the school management information systems, especially for SMA 78 Jakarta as a case study. Included in the system are the students and teachers data management, the management of school tuition, and the management of learning materials and assignments for students. This research uses data collection methods, with a literature study, questionnaires, interviews, observation, and studying the data obtained from the school. Analyses were performed on the results of questionnaires, interviews and observations to identify user needs. The design used conceptual and logical database system design. The result achieved is the application for school management information system that can be used by students, teachers and school officials in supporting learning process and school administration. The developed application is expected to be a medium for students and teachers to share information in teaching and learning activities and administrative processes.
\end{abstract}

Keywords: information system, school management, administration, database, learning material.

\begin{abstract}
ABSTRAK
Database untuk mengelola data berkaitan dengan siswa dan sekolah diperlukan untuk mendukung aplikasi teknologi informasi yang dipergunakan. Penelitian ini bertujuan menganalisis dan merancang sistem basis data yang mendukung sistem informasi manajemen sekolah, khususnya untuk SMA Negeri 78 Jakarta sebagai studi kasus. Termasuk di dalam sistem adalah pengelolaan data siswa dan guru, pengelolaan iuran sekolah, hingga pengelolaan materi pembelajaran dan tugas untuk siswa. Penelitian menggunakan metode pengumpulan data, dengan studi pustaka, kuesioner, wawancara, observasi, serta mempelajari data-data yang didapat dari sekolah. Analisis dilakukan terhadap hasil kuesioner, wawancara dan observasi untuk mengidentifikasi kebutuhan user. Perancangan menggunakan perancangan sistem basis data konseptual dan logikal. Hasil yang dicapai adalah adanya aplikasi untuk sistem informasi manajemen sekolah yang dapat digunakan oleh siswa, guru dan pegawai sekolah dalam mendukung proses pembelajaran juga proses administrasi sekolah. Aplikasi yang akan dikembangkan diharapkan dapat menjadi media bagi siswa dan guru untuk berbagi informasi dalam kegiatan belajar mengajar dan proses administrasi.
\end{abstract}

Kata kunci: sistem informasi, manajemen sekolah, administrasi, basis data, materi pembelajaran 


\section{PENDAHULUAN}

Teknologi informasi yang juga berkembang pesat saat ini, dapat mendukung kebutuhan sekolah-sekolah dalam memberikan layanan maupun informasi secara cepat dan akurat. Dalam hal ini, yang dimaksud dengan informasi adalah data yang telah diproses sedemikian rupa sehingga dapat meningkatkan pengetahuan orang yang menggunakan data tersebut (Hoffer, Prescott dan McFadden, 2005, p6). Serupa dengan pendapat Turban, Rainer, dan Porter (2005, p38), bahwa informasi adalah kumpulan fakta atau data yang diatur dalam beberapa cara sehingga memiliki arti bagi penggunanya. Informasi yang berkaitan dengan sekolah dapat berupa profil sekolah, guru dan siswa, informasi iuran sekolah atau informasi nilai siswa.

Dengan teknologi informasi sekolah-sekolah dapat meningkatkan daya saingnya. Segala informasi yang berkaitan dengan sekolah dapat dengan mudah dan cepat diakses oleh siswa, guru, orang tua maupun masyarakat yang membutuhkannya. Pemanfaatan teknologi informasi juga diperlukan dalam proses pengelolaan sekolah, baik dalam hal pengelolaan administrasi akademik, dan administrasi kepegawaian karena teknologi informasi adalah suatu istilah kontemporer yang mendeskripsikan kombinasi dari teknologi komputer (perangkat keras dan piranti lunak) dengan teknologi telekomunkasi (data, gambaran, dan suara) (Whitten et al 2004, p.8). Sementara menurut Connolly dan Begg (2005, p.282), sstem informasi adalah sebuah sumber yang memungkinkan untuk mengumpulkan, mengatur dan mengontrol informasi yang mencakup keseluruhan pengorganisasian sistem.

Selain itu, kebutuhan aplikasi database yang dapat mengelola data dan informasi sekolah, manajemen sekolahan, dan konten-konten pengajaran dan pembelajaran. Teknologi informasi juga dapat dimanfaatkan sebagai sarana pembelajaran, mendukung berbagai hal yang berkaitan dengan kesiswaan serta kegiatan akademis, seperti pengumuman untuk siswa, pengumpulan tugas, dan proses pengolahan nilai. Dimana basis data sendiri merupakan kumpulan data-data yang disimpan dalam suatu format yang telah distandarisasi, dirancang untuk dibagikan kepada banyak user (Post, 2005, p.2).

SMA Negeri 78 belum memaksimalkan penggunaan dan pemanfaatan ternologi informasi ini. Walaupun sistem absensi siswa dan guru telah mempergunakan finger print, pemanfaatannya masih terbatas. Misalnya orang tua murid tidak bisa memperoleh informasi kehadiran anaknya di sekolah, atau informasi mengenai iuran sekolah yang telah dibayarkan maupun nilai siswa. Masalah lainnya siswa tidak dapat mengakses pengumuman sekolah seperti jadwal ujian. Jika siswa tidak hadir ke sekolah, ia tidak dapat melihat nilai hasil ulangan maupun ujian. Guru pun tidak dapat memberikan tugas maupun materi belajar jika berhalangan hadir.

Penelitian ini membahas mengenai pemanfaatan teknologi informasi untuk pengelolaan administrasi dan akademis siswa dengan mengulas aspek administrasi berbasis komputer, sistem informasi nilai dan penyebaran materi pembelajaran dan tugas untuk siswa melalui web sekolah. Penyebaran materi belajar dan tugas dapat menggunakan konsep e-learning, yaitu proses belajar secara efektif yang dihasilkan dengan cara menggabungkan penyampaian materi secara digital yang terdiri dari dukungan dan layanan dalam belajar (Vaughan Waller, 2001).

\section{METODE}

Penelitian ini berdasarkan pada kenyataan semakin berkembangnya kebutuhan informasi dan pengelolaan data siswa yang cepat dan akurat. Data yang digunakan adalah data primer, yang 
diperoleh dengan melakukan observasi melalui kuisioner kepada kepala sekolah, guru, dan siswa yang pelaksanaannya kami lakukan dari tanggal 28 September 2010 sampai dengan tanggal 1 Oktober 2010. Kuesioner diberikan kepada siswa dan guru dengan tujuan untuk mengetahuai kondisi ketertarikan siswa dan guru SMA Negeri 78 Jakarta Jakarta terhadap bidang TI khususnya di bidang informasi, seperti seberapa sering mereka menggunakan komputer, seberapa jauh mereka memanfaatkan dan menggunakan internet untuk kebutuhan informasi yang terkait dengan nilai, materi pelajaran dan informasi sekolah lainnya.

Pengumpulan data dengan metode wawancara dilakukan kepada guru dan kepala sekolah yang bertujuan untuk mengetahui sistem yang sedang berjalan di sekolah, riwayat sekolah, mengetahui seberapa jauh keterlibatan internet untuk mendukung proses belajar mengajar serta mengetahui partisipasi apa saja yang guru inginkan jika aplikasi ini diterapkan di sekolah mereka. Metode pengumpulan data primer juga dilakukan dengan mempelajari data-data dan form dari SMA Negeri 78 Jakarta yang bertujuan untuk mengumpulkan fakta mengenai sistem yang sedang berjalan dan kebutuhan sistem.

Data kualitatif/data sekunder didapat dari studi kepustakaan mengenai sistem informasi manajeman, sistem pembelajaran jarak jauh, dan hal lain yang berhubungan dengan metode belajar melalui internet. Pengumpulan data sekunder melalui studi kepustakaan mencakup segala hal yang berhubungan dengan topik pembahasan yang keseluruhannya bersifat teoritis untuk menunjang pembahasan permasalahan pemanfaatan teknologi informasi untuk pengelolaan administrasi dan akademis siswa

Pengolahan dan analisis data, dilakukan sesuai dengan batasan penelitian dengan tujuan dapat menjawab permasalahan yang ada. Setelah data diolah, diharapkan didapat bentuk ideal dari pemanfaatan teknologi informasi untuk pengelolaan administrasi dan akademis siswa.

\section{HASIL DAN PEMBAHASAN}

Sistem Informasi Manajemen sekolah merupakan konsep manajemen sekolah yang mengkonversi manajemen sekolah secara manual ke Sistem manajemen sekolah berbasis komputer. Sistem Informasi Manajemen sekolah adalah proses manajemen data akademik dan data pendukung akademik secara mudah, cepat dan efisien.

\section{Sistem yang Berjalan}

Sistem yang sudah berjalan di SMA Negeri 78 Jakarta dilakukan secara semi komputerisasi, dimana sebagian proses telah menggunakan aplikasi komputer, seperti sistem absensi pegawai dan siswa secara umum yang telah menggunakan sistem absensi finger print yang terhubung dengan server dan komputer, tetapi masih terdapat beberapa proses yang masih belum terkomputerisasi, seperti pembuatan jadwal belajar mengajar, pembuatan jadwal ujian, pengajuan saran dan hal lain yang berkaitan dengan kegiatan siswa

Untuk pengolahan data yang ada di sekolah, pemerintah pusat dalam hal ini DEPDIKNAS (DIKMENTI) telah membuatkan suatu sistem yang bisa dipakai oleh semua sekolah di seluruh Indonesia, yaitu Sistem Administrasi Sekolah (SAS). Namun, dalam 3 tahun terakhir SMA Negeri 78 Jakarta tidak menggunakan sistem tersebut, karena Sistem Administrasi Sekolah (SAS) dianggap tidak sesuai dengan kurikulum yang mereka terapkan dimana SMA Negeri 78 menerapkan Sistem Kredit Semester (SKS), sehingga SMA Negeri 78 Jakarta menggunakan sistem sekolah mereka sendiri yaitu Sistem Informasi Manajemen (SIM). 
Mulai pada tahun akademik 2007-2008, proses Kegiatan Belajar Mengajar (KBM) di sekolah ini berdasarkan Sistem Kredit Semester (SKS) dimana masing-masing pelajaran diberi jumlah kredit tertentu. Siswa dapat memilih peminatan antara ilmu pengetahuan alam atau ilmu pengetahuan sosial dimulai dari kelas X semester 2. Dengan menggunakan sistem ini sekolah dapat memberikan instruksi berbeda untuk setiap siswa sesuai kebutuhan individu. Sekolah juga menyediakan pembimbing akademis untuk membantu dan membimbing para siswa dalam pemilihan subjek dan kredit. Sistem ini mempersiapkan siswa untuk pendidikan yang lebih tinggi di perguruan tinggi dan universitas di mana mereka akan dihadapkan dengan metode pendidikan yang sama. Sistem Kredit Semester di SMA Negeri 78 ini juga dilaksanakan dengan menggunakan sistem moving class sesuai dengan penjurusan masing-masing kelas. Gambar 1 di bawah ini memuat gambaran sistem administrasi sekolah yang sedang berjalan.

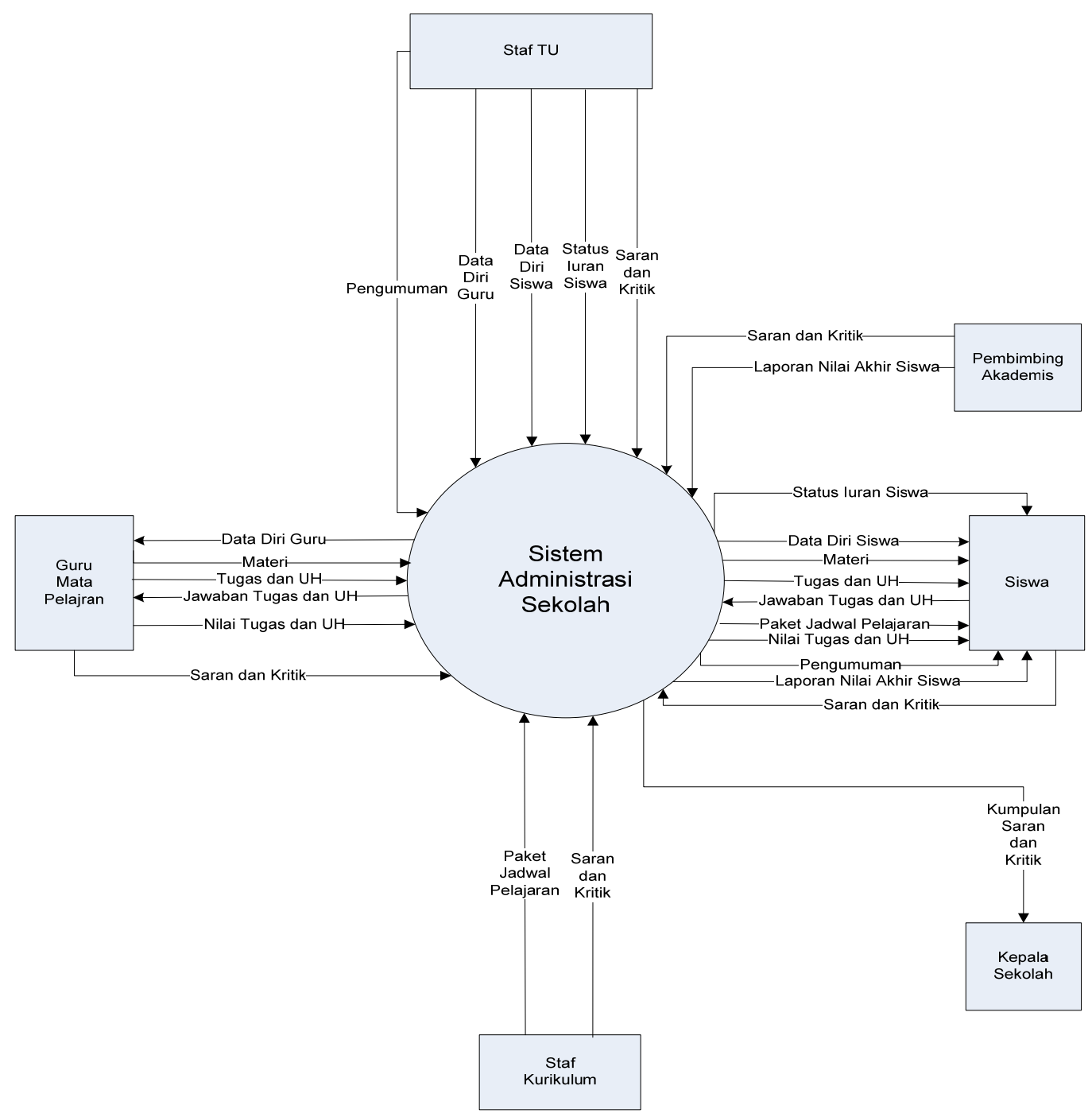

Gambar 1. Diagram konteks sistem administrasi sekolah yang sedang berjalan.

\section{Permasalahan yang Dihadapi}

Sistem administrasi sekolah (SAS) yang disediakan oleh pemerintah dalam hal ini pihak DEPDIKNAS DKI Jakarta sudah bagus jika diterapkan di masing-masing sekolah di kawasan DKI Jakarta termasuk di SMA Negeri 78 sendiri. Akan tetapi, content dari SAS kurang cocok jika 
diterapkan di SMA Negeri 78 yang telah menggunakan sistem kredit semester dalam proses kegiatan belajar mengajarnya. Karena itu SMA Negeri 78 memiliki sistem sendiri untuk diterapkan yaitu menggunakan sistem informasi manajemen (SIM).

Beberapa masalah umum yang dihadapi dalam sistem berjalan adalah: (1) masih membutuhkan waktu yang cukup lama ketika pihak sekolah ingin melakukan proses pengaksesan data pegawai dan siswa, melihat data keuangan, memasukkan nilai siswa, memasukkan data kelas serta membuat jadwal pelajaran dan jadwal ujian; (2) mengetahui nilai harus melihat di papan pengumuman atau melihat langsung melalui guru atau pembimbing akademisnya; (3) tugas dari guru diberikan pada saat kegiatan belajar mengajar berlangsung dan pengumpulan tugas harus dengan menemui guru mata pelajaran tersebut; (4) waktu yang tersedia di kelas terbatas, sehingga kesempatan antara siswa dan guru untuk berdiskusi menjadi berkurang; (5) siswa yang berhalangan hadir dan tidak mendapatkan pengajaran disekolah, sehingga hal ini akan menghambat proses pembelajaran; (6) mengetahui jadwal pelajaran dan ujian harus dengan melihatnya di papan pengumuman; (7) saran dan kritik hanya dapat diberikan ke kotak saran dengan mengisi kertas saran yang disediakan; (8) sulitnya mengeluarkan pengumuman yang bisa dijangkau oleh semua masyarakat sekolah.

\section{Alternatif Pemecahan Masalah}

Setelah mengidentifikasi masalah di SMA Negeri 78 Jakarta, peneliti mengusulkan untuk mengunakan sistem yang berbasis web. Beberapa pemecahan masalah yang diharapkan: (1) mempermudah pihak sekolah dalam pendataan siswa dan pegawai, melihat data keuangan, memasukkan nilai siswa, memasukkan data kelas serta membuat jadwal pelajaran dan jadwal ujian; (2) menampilkan nilai siswa, jadwal mengajar guru, jadwal pelajaran siswa, jadwal ujian, pengumuman sekolah, informasi data diri siswa dan guru; (3) siswa dapat mengunduh materi dan tugas serta mengunggah jawaban tugas yang diberikan oleh guru; (4) furu dapat mengunggah materi dan tugas, juga mempermudah guru dalam menyimpan dokumen tugas siswa; (5) mengajukan saran dan kritik dari manapun; (6) siswa dan guru dapat berdiskusi jarak jauh mengenai materi pelajaran.

\section{Perancangan Sistem yang Diusulkan}

Rancangan sistem yang diusulkan digambarkan dengan diagram konteks (Gambar 2), diagram nol (Gambar 3), dan diagram level $n$ (Gambar 4 - 8), yang menjelaskan proses-proses yang terdapat dalam sistem administrasi sekolah yang baru, berikut dengan perancangan basis data konseptual (Gambar 9), logikal (Gambar 10) sesuai dengan tahapan siklus hidup aplikasi basis data (Connolly dan Begg, 2005). 


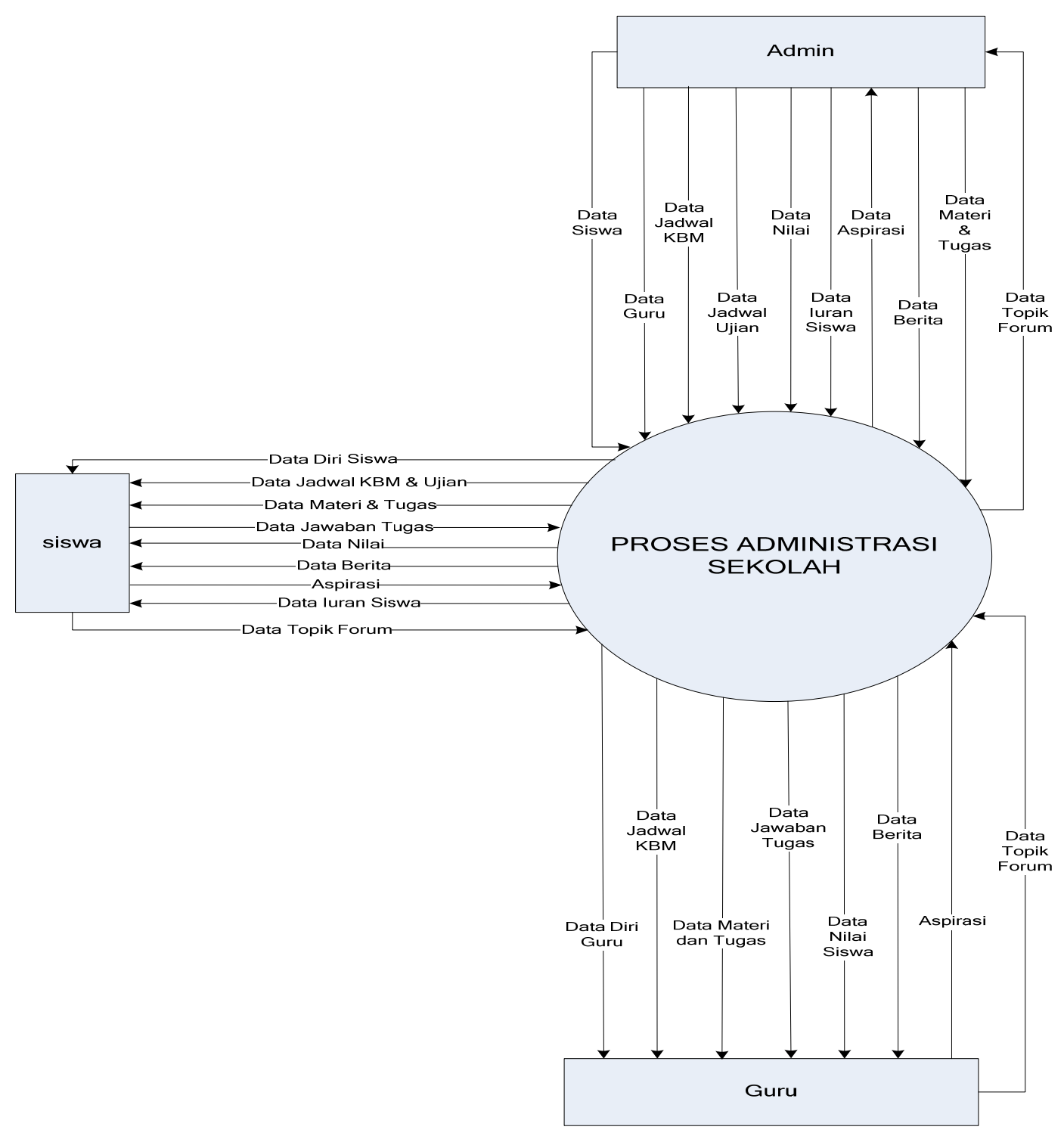

Gambar 2. Diagram konteks sistem administrasi sekolah yang diusulkan. 


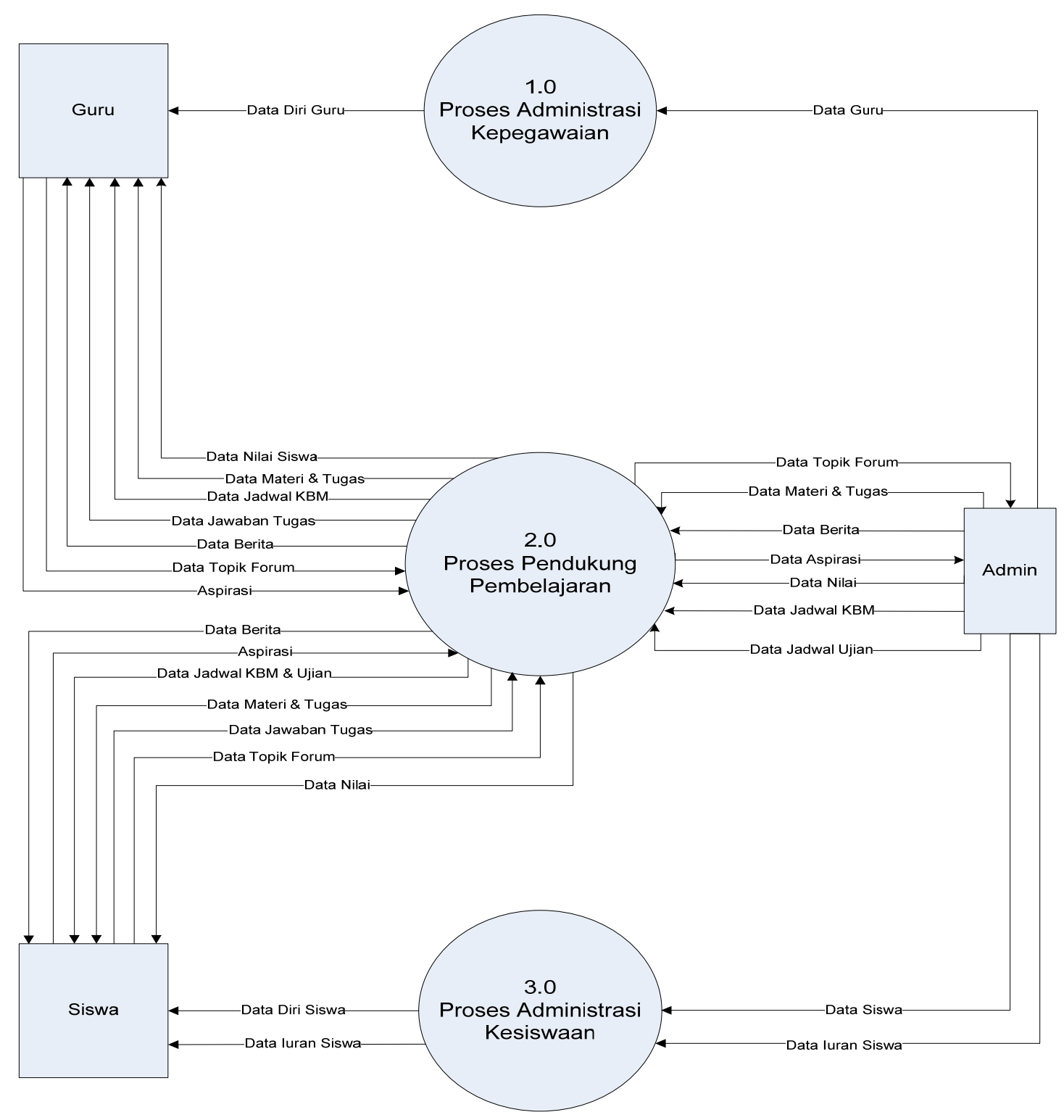

Gambar 3. Diagram level 0 pada sistem administrasi sekolah yang diusulkan. 


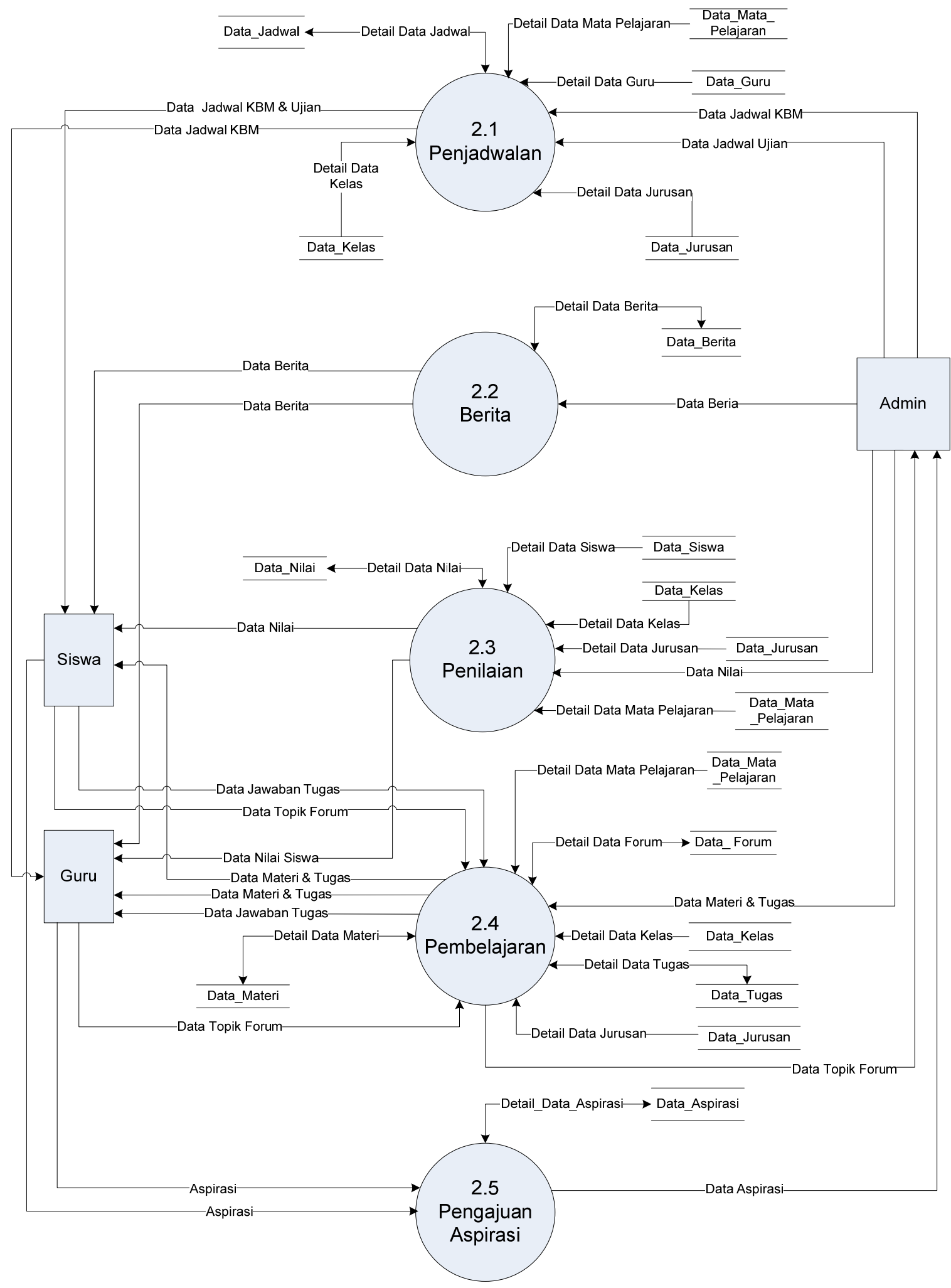

Gambar 4. Diagram level 1 proses 2 sistem administrasi sekolah yang diusulkan. 


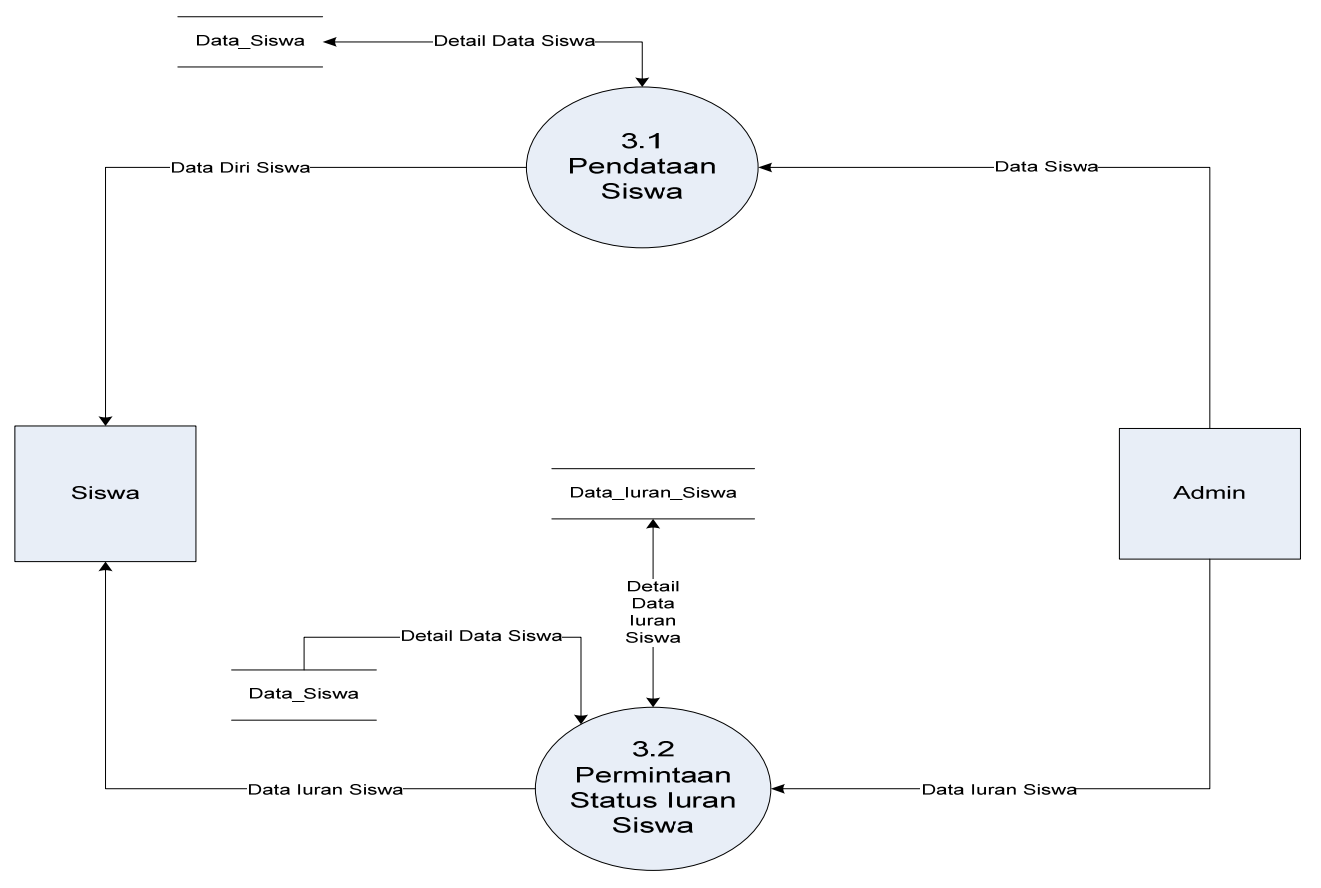

Gambar 5. Diagram level 1 proses 3 sistem administrasi sekolah yang diusulkan.

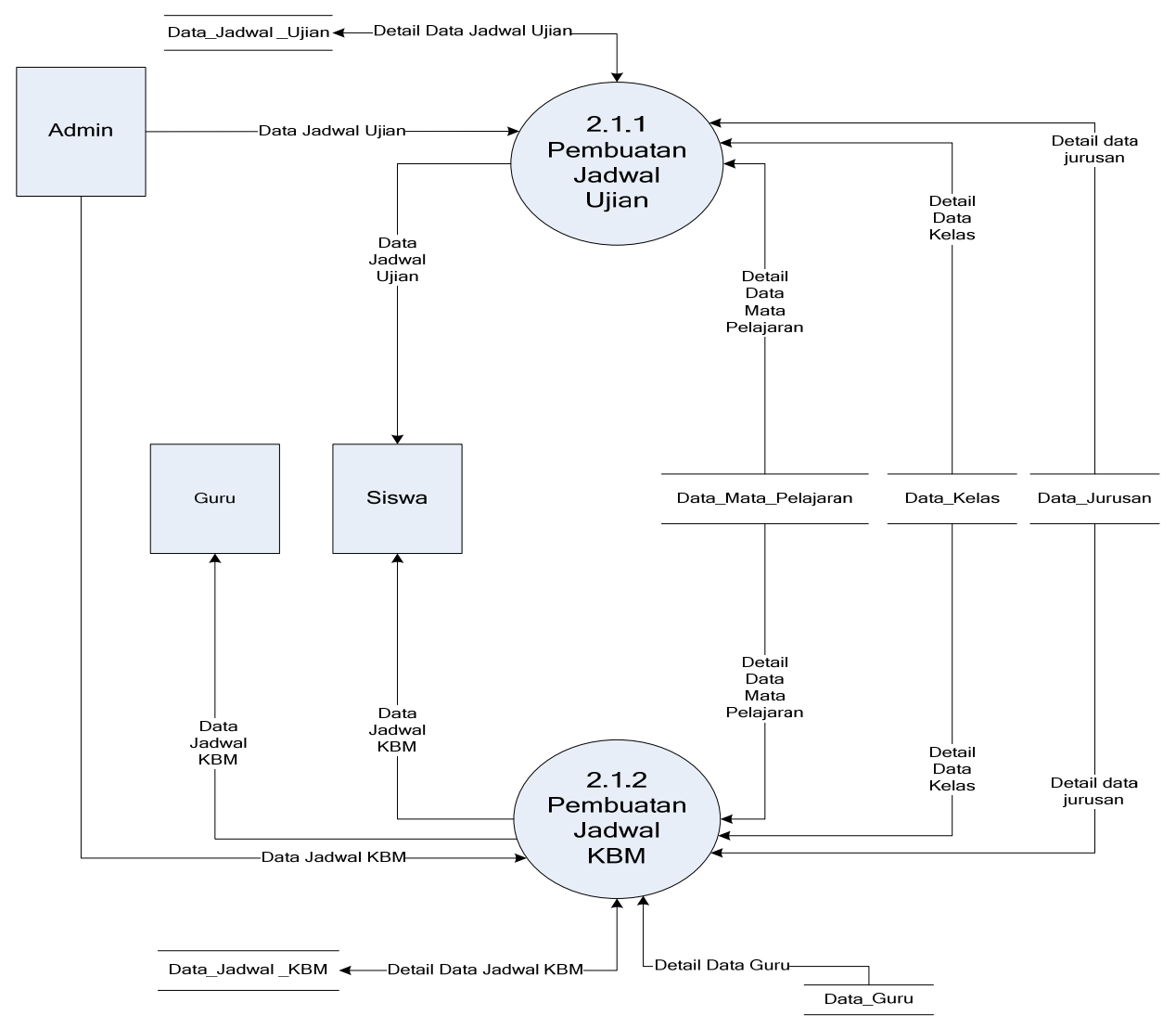

Gambar 6. Diagram level 2 proses 2.1 sistem administrasi sekolah yang diusulkan. 


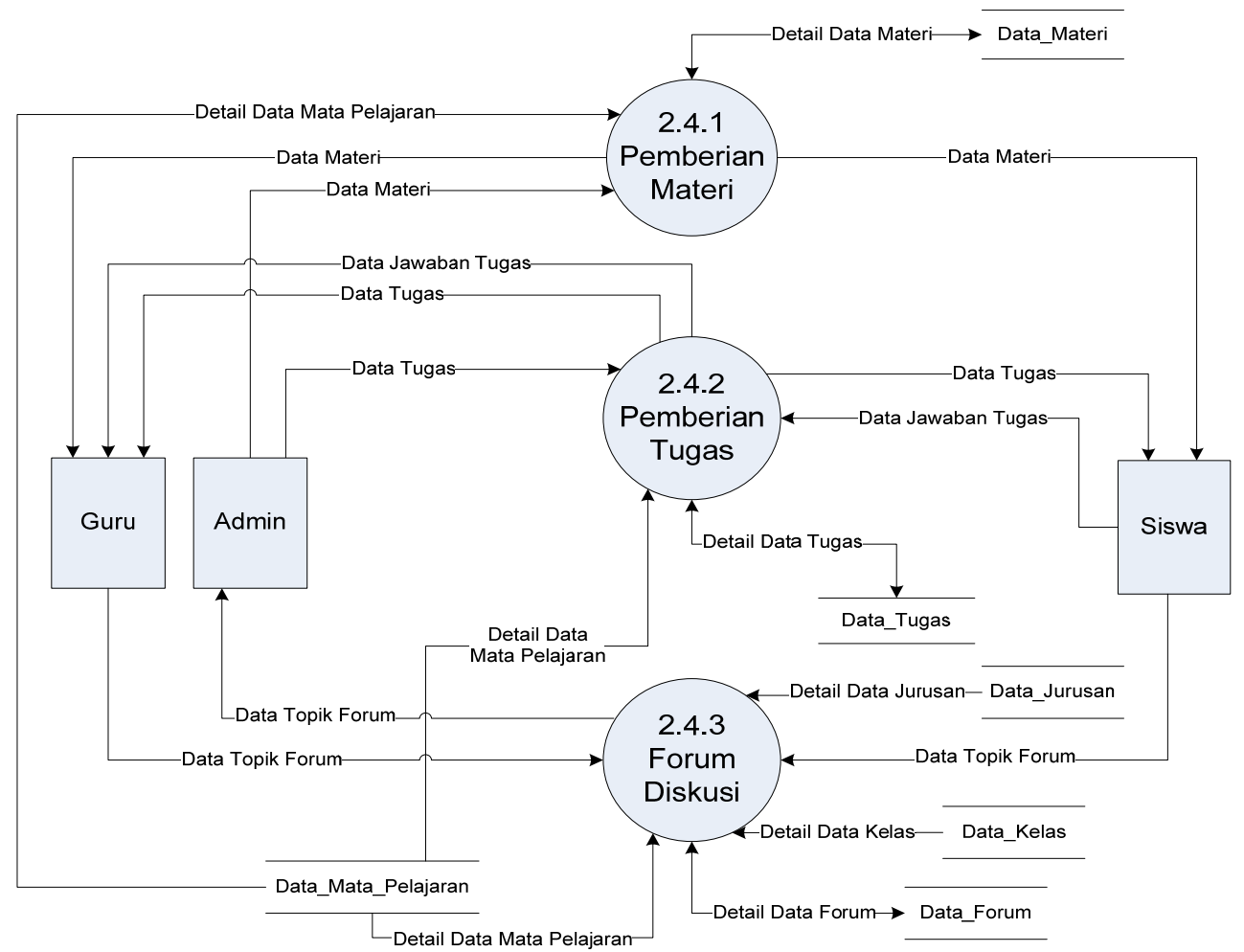

Gambar 7. Diagram level 2 proses 2.4 sistem administrasi sekolah yang diusulkan.

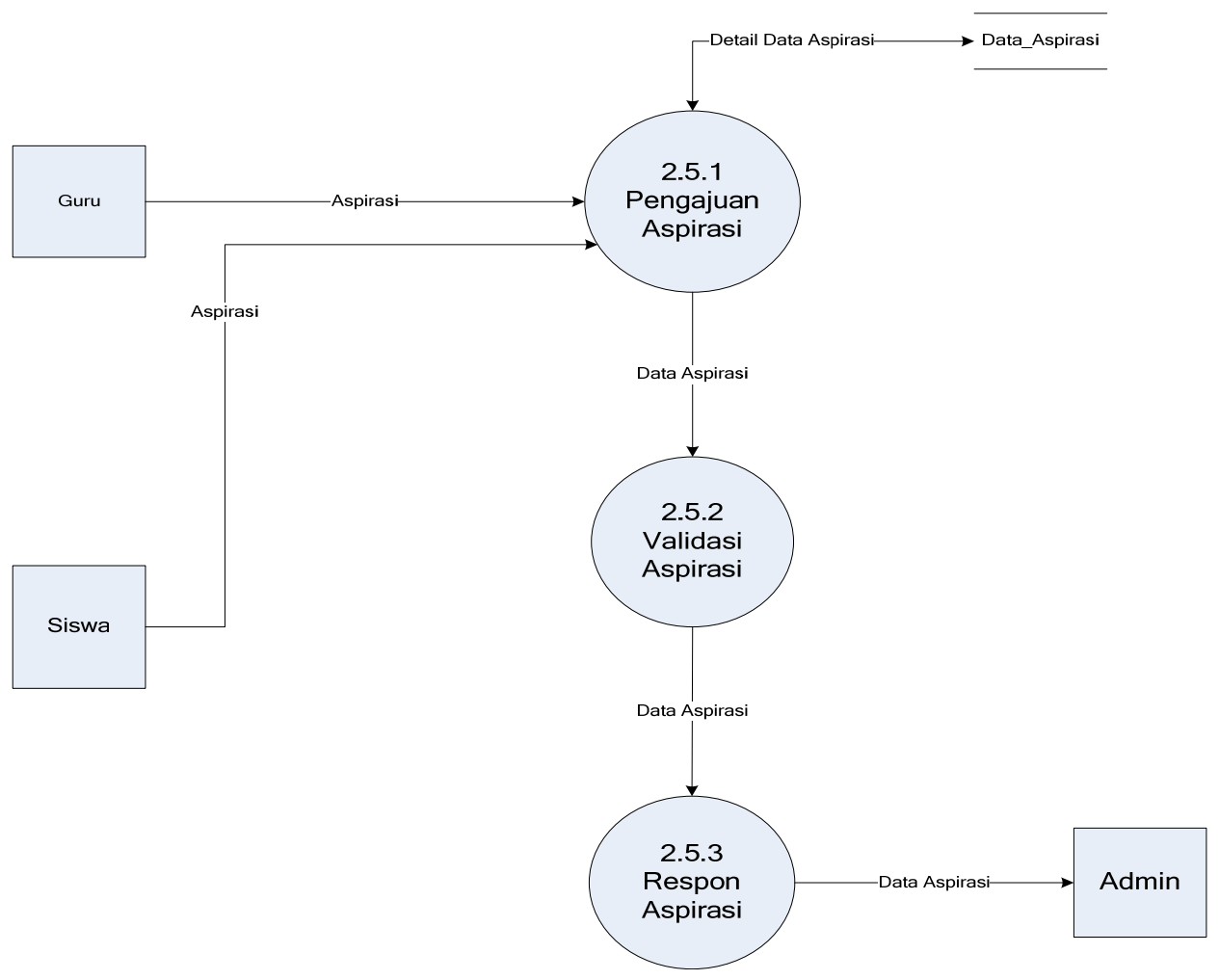

Gambar 8. Diagram level 2 proses 2.5 sistem administrasi sekolah yang diusulkan. 


\section{Perancangan Basis Data Konseptual}

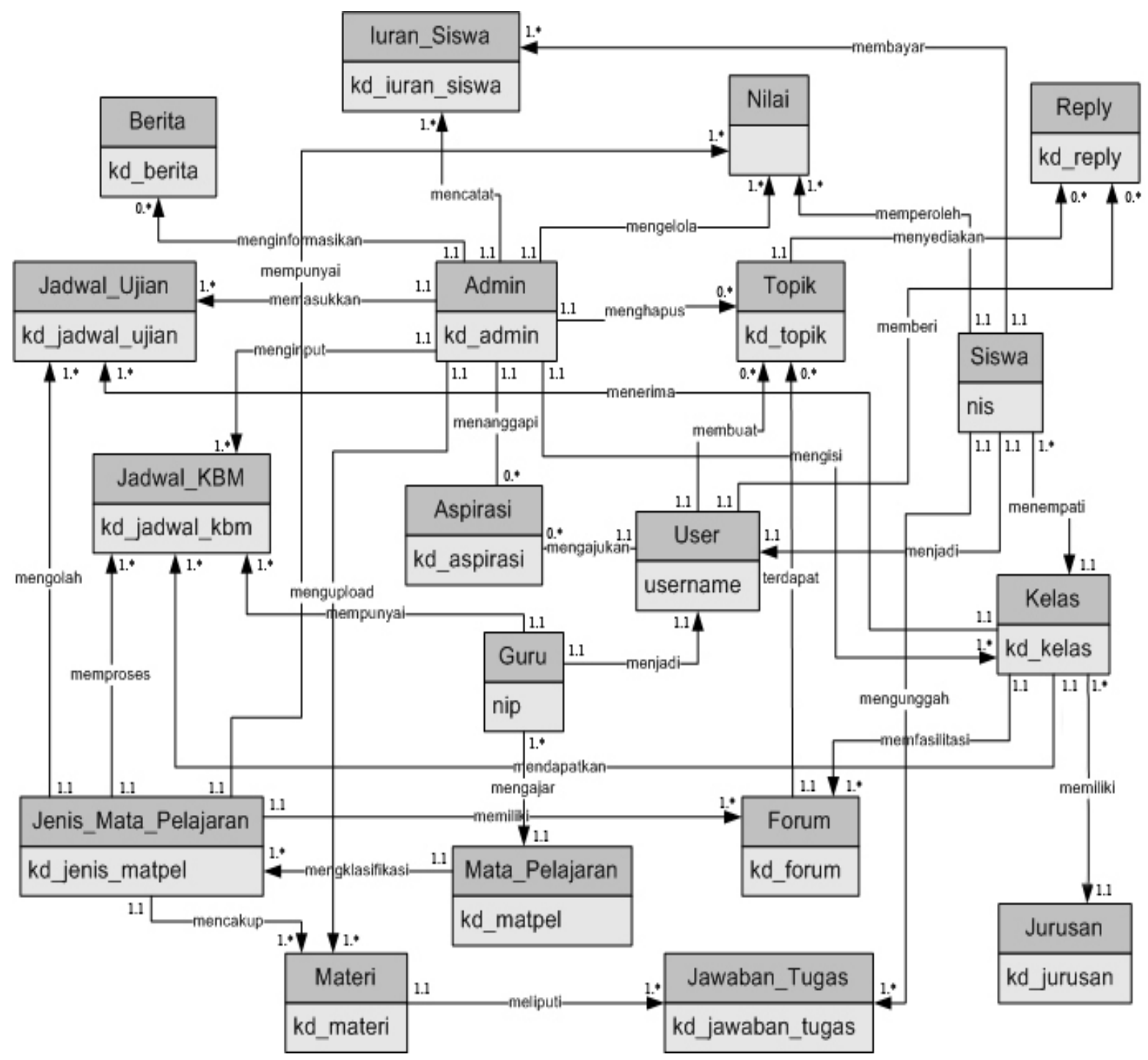

Gambar 9. E-R diagram dengan primary key. 


\section{Perancangan Basis Data Logical}

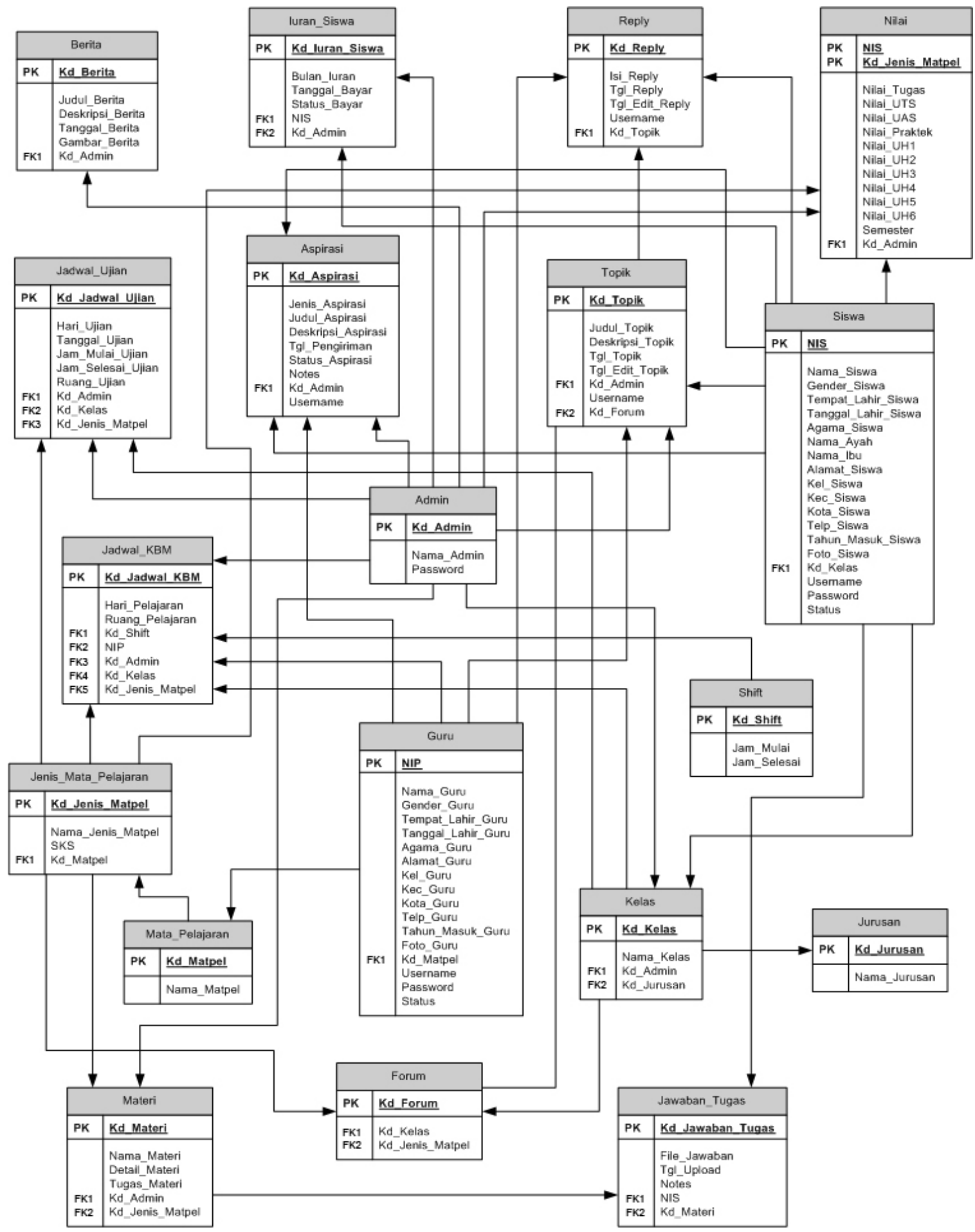

Gambar 10. E-R diagram model global logikal. 


\section{Perancangan Layar}

Gambar 11 - 13 adalah struktur menu yang dibuat untuk perancangan layar.

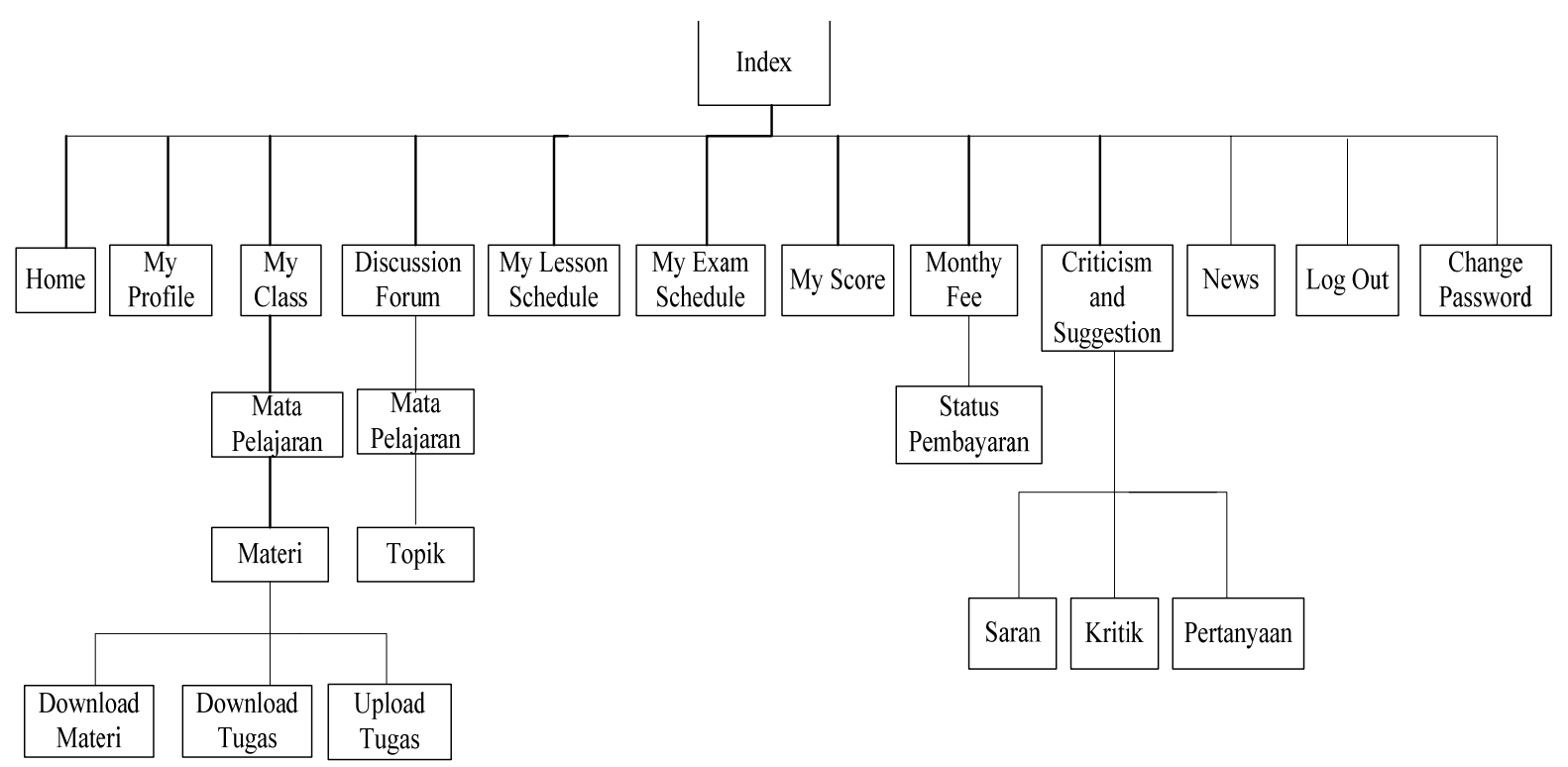

Gambar 11. Struktur menu siswa.

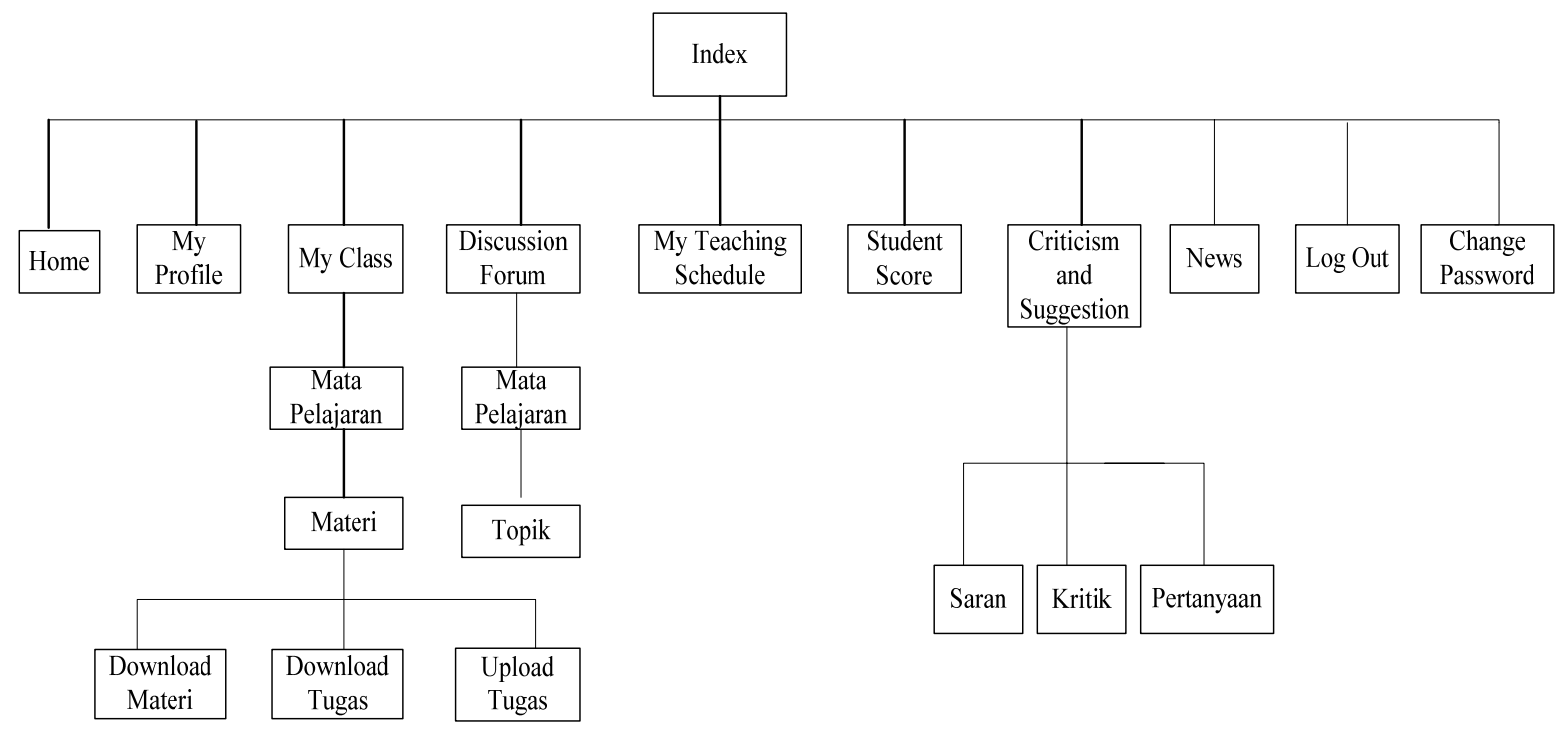

Gambar 12. Struktur menu guru. 


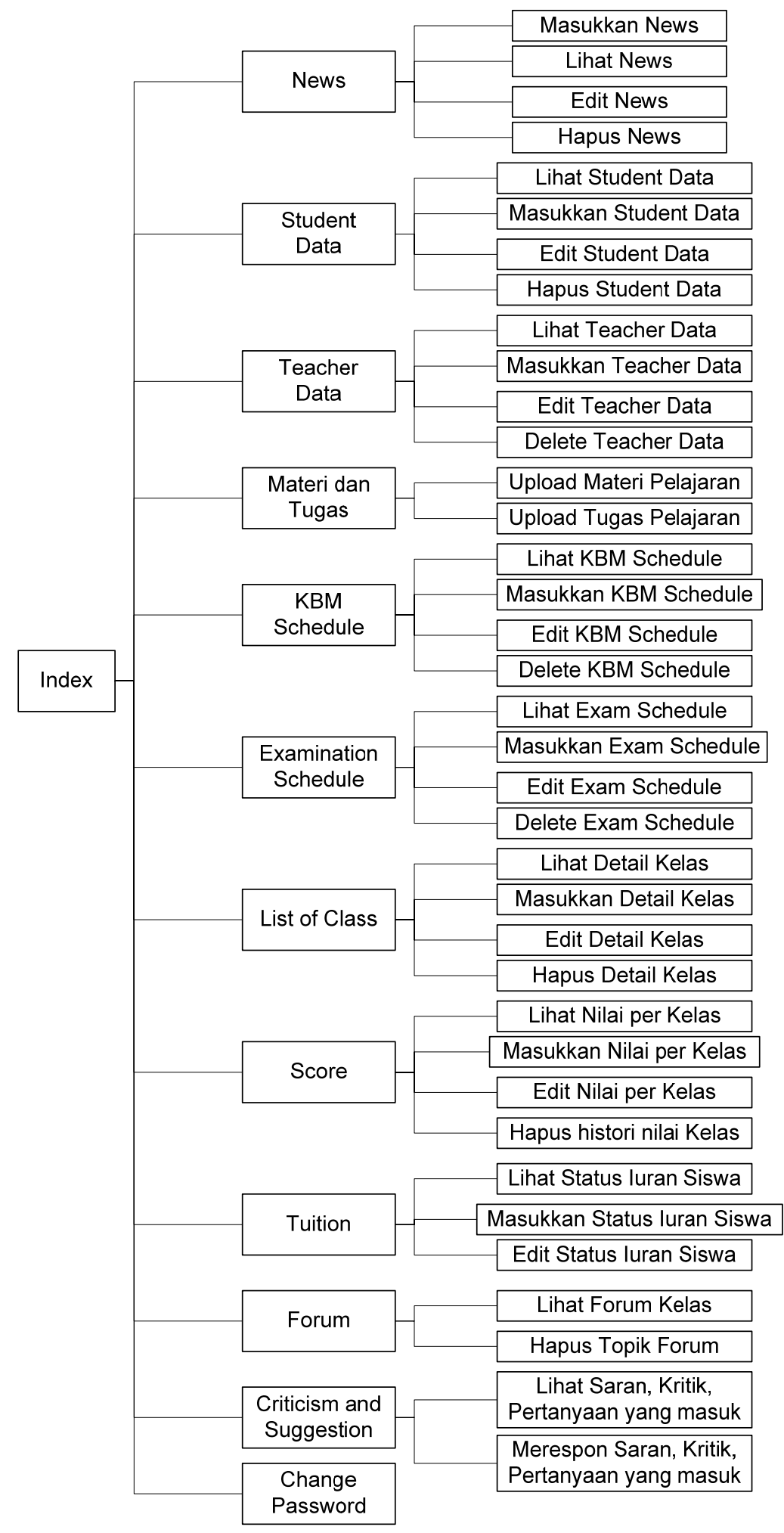

Gambar 13. Struktur menu admin . 


\section{Halaman Siswa}

Gambar 13 menampilkan antarmuka halaman siswa Home yang dirancang. Pada halaman ini, siswa dapat melihat My Profile untuk melihat data pribadinya, My Class untuk melihat daftar mata pelajaran pada semester berjalan, mengunduh materi pelajaran dan mengunggah tugas siswa.

Dengan memilih Discussion Forum, siswa dapat berdiskusi dengan siswa dan guru lain dalam satu kelas. Siswa dapat membuat topik forum, reply dan memperbaharui isi postingnya. My Lesson Schedule, untuk melihat jadwal mata pelajaran yang diambil di semester berjalan. My Examination Schedule, untuk melihat jadwal ujian, My Score, untuk melihat nilai mata pelajaran yang diambil di semester berjalan. Monthly Fee, untuk melihat status iuran setiap bulannya. dan Criticism and Suggestion, untuk mengajukan aspirasi yang berupa saran, kritik dan pertanyaan yang nantinya akan direspon oleh admin. Untuk keluar dari menu-menu ini, siswa dapat mengklik Log Out. Berikut ini adalah salah satu tampilan sub menu Lesson pada halaman siswa (Gambar 14).

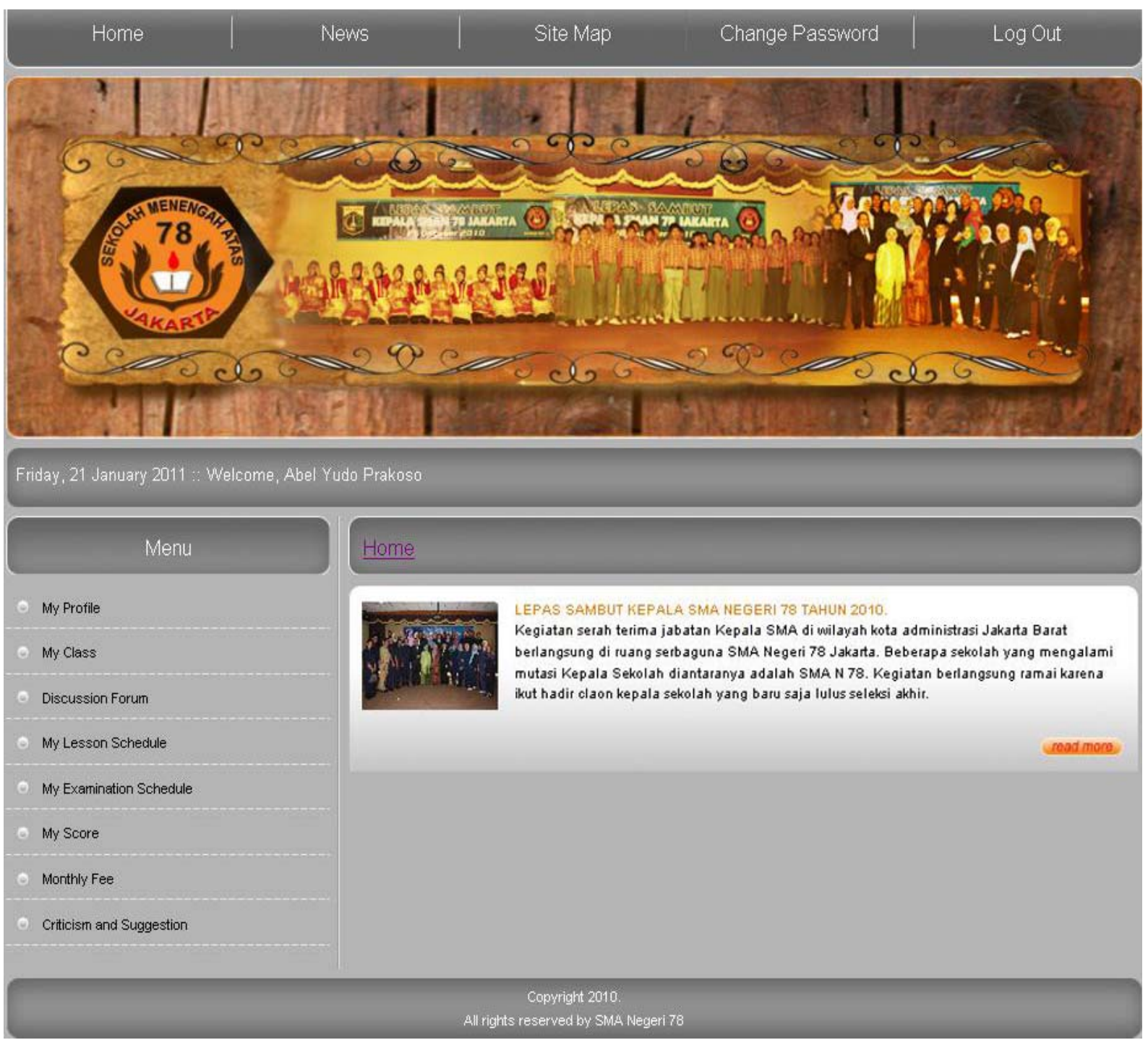

Gambar 13. Halaman siswa-Home. 


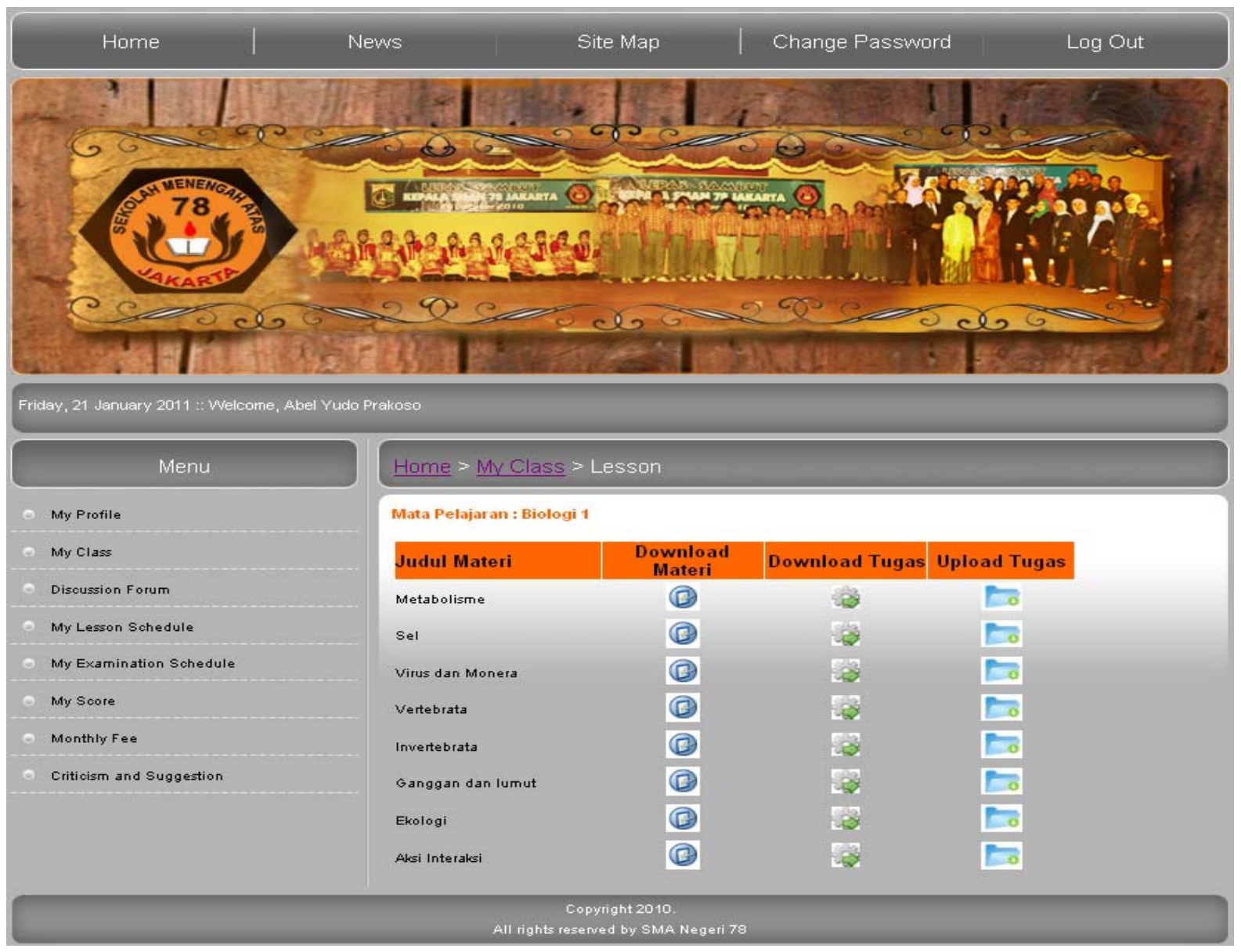

Gambar 14. Halaman siswa - Myclass - Lesson.

\section{Halaman Guru}

Pada halaman ini, guru dapat melihat My Profile untuk melihat data pribadinya, My Class untuk melihat daftar mata pelajaran yang diajar, mengunduh materi pelajaran, tugas dan mengunduh jawaban tugas tiap siswa. Tombol My Teaching Schedule untuk melihat jadwal mata pelajaran yang diajar di semester berjalan, Student Score untuk melihat nilai mata pelajaran dari murid didiknya. Setelah memilih "List Nilai”, guru dapat melihat daftar nilai siswa tiap kelas dalam format pdf. Pada Discussion Forum, guru dapat berdiskusi dengan siswa lain dalam satu kelas. Guru dapat membuat topik forum, reply dan mengedit postingannya. Criticism and Suggestion, untuk mengajukan aspirasi yang berupa saran, kritik dan pertanyaan yang nantinya akan direspon oleh admin. Untuk keluar dari menu-menu ini, siswa dapat mengklik Log Out. Berikut ini adalah beberapa tampilan halaman guru pada Home (Gambar 15) dan Lesson (Gambar 16). 


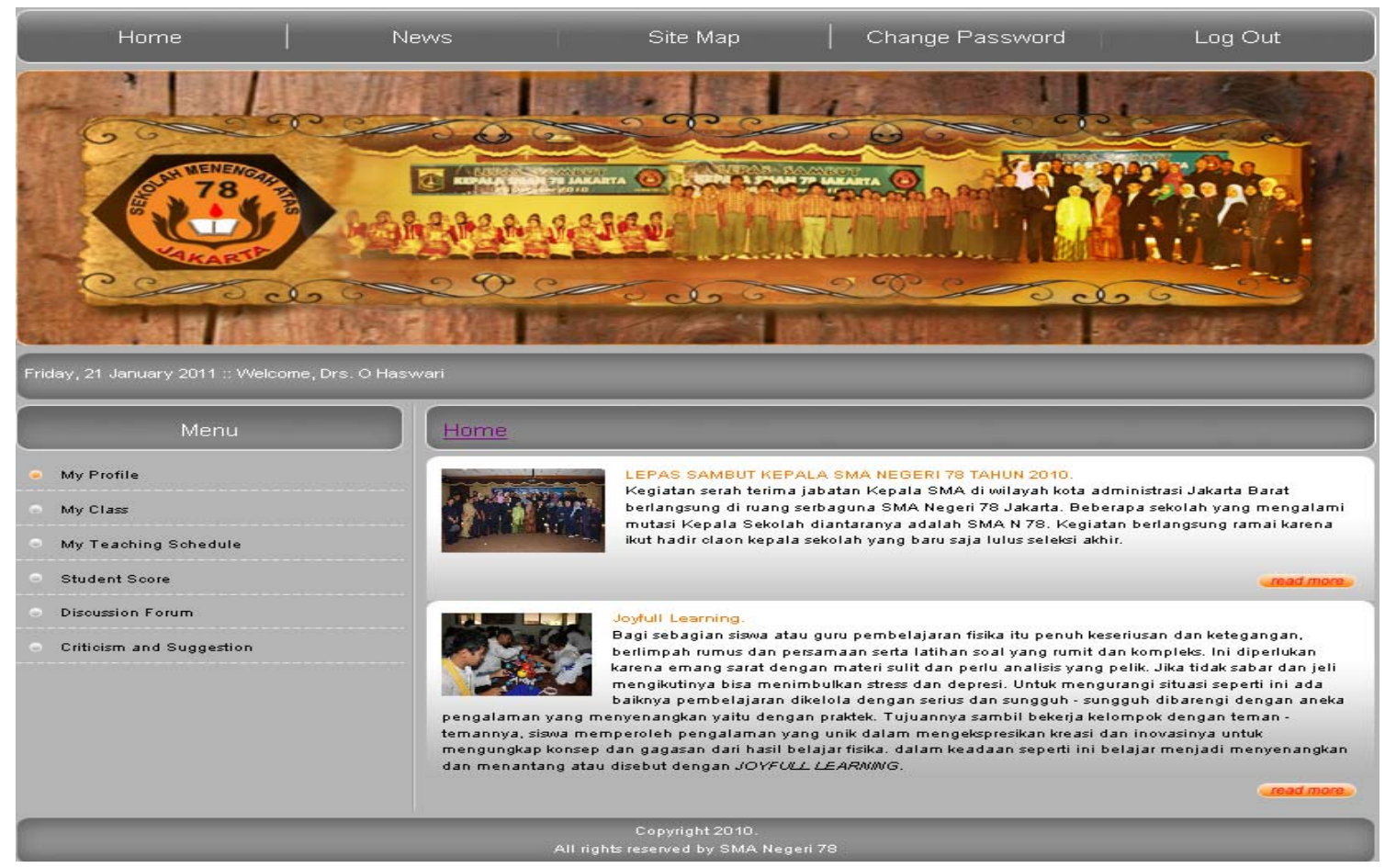

Gambar 15. Halaman guru-Home.

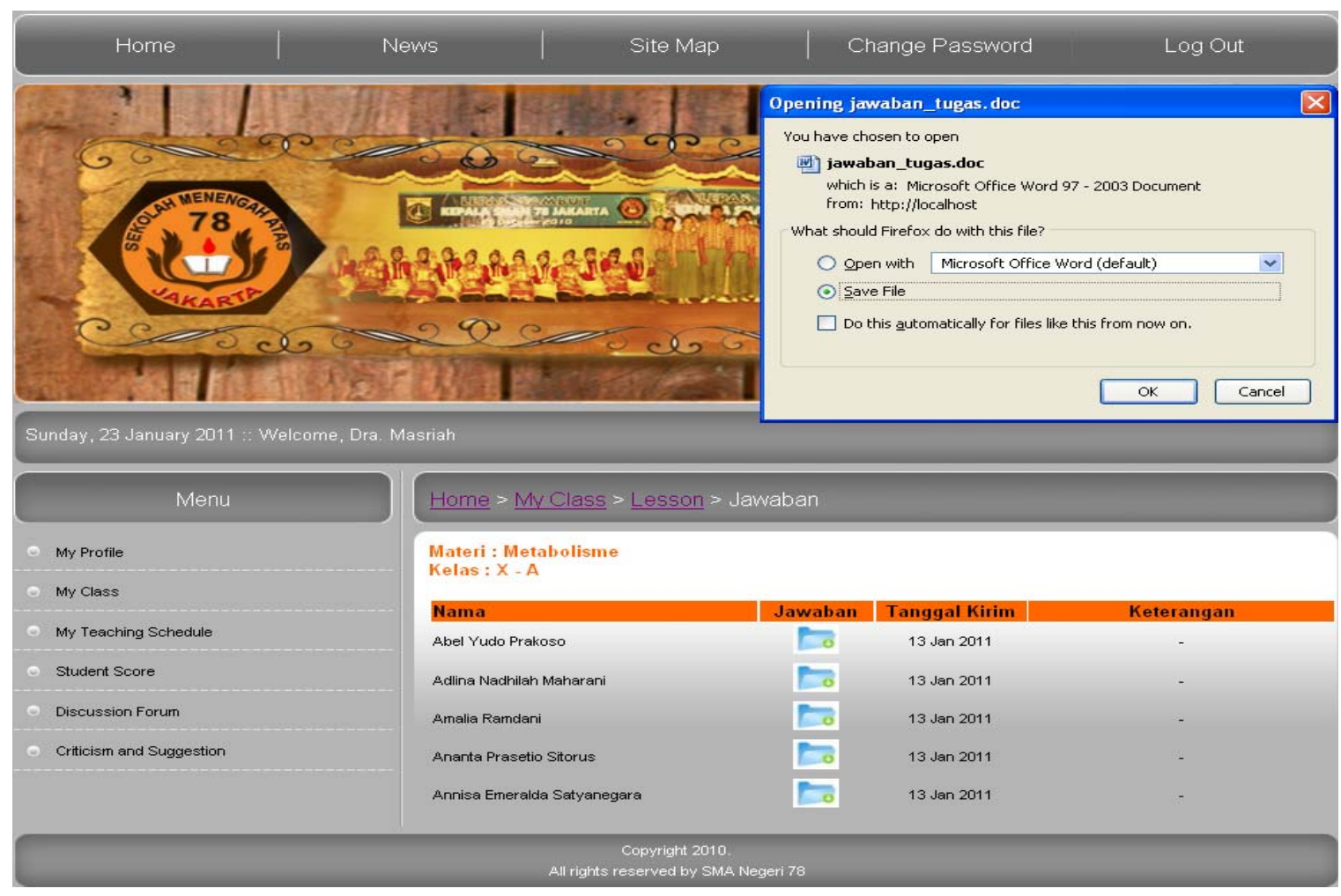

Gambar 16. Halaman guru-MyClass-Lesson-jawaban tugas. 


\section{Halaman Admin}

Pada halaman ini admin dapat melihat Insert News, Student Data untuk melihat data siswa, memasukkan, memperbaharui dan menghapus data siswa dengan mengklik "delete", serta melakukan pencarian data siswa berdasarkan NIS atau Nama.

Tombol Teacher Data, untuk melihat data guru, memasukkan, memperbaharui dan menghapus data guru dengan mengklik "delete", serta melakukan pencarian data guru berdasarkan NIP atau Nama. Jika memilih tombol Materi dan Tugas, admin dapat mengunggah data materi pelajaran dan data tugas sesuai dengan mata pelajaran.

KBM Schedule, untuk melihat, memasukkan, memperbaharui dan menghapus jadwal KBM. Examination Schedule, untuk melihat, memasukkan, memperbaharui dan menghapus jadwal ujian. List of Class, untuk melihat, mengisi dan menghapus data kelas. Tombol Score, digunakan untuk memasukkan nilai tiap siswa berdasarkan kelas dan mata pelajaran, memperbaharui nilai tiap siswa masing-masing kelas berdasarkan mata pelajaran tertentu, serta menghapus nilai kelas tertentu.

Gambar 17 merupakan tampilan Home untuk halaman admin, dan Gambar 18 merupakan tampilan menu Edit Score.

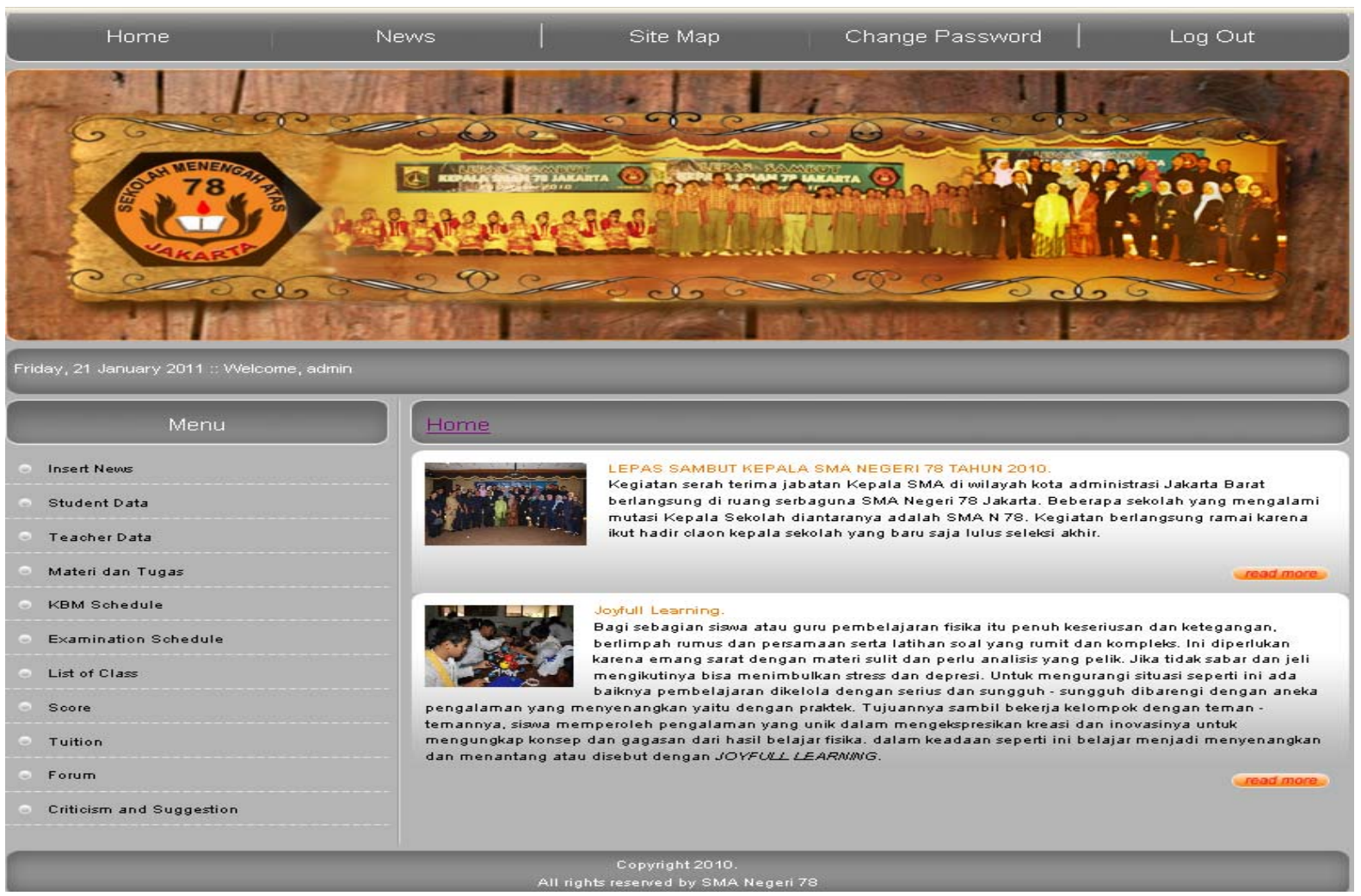

Gambar 17. Halaman admin-Home. 


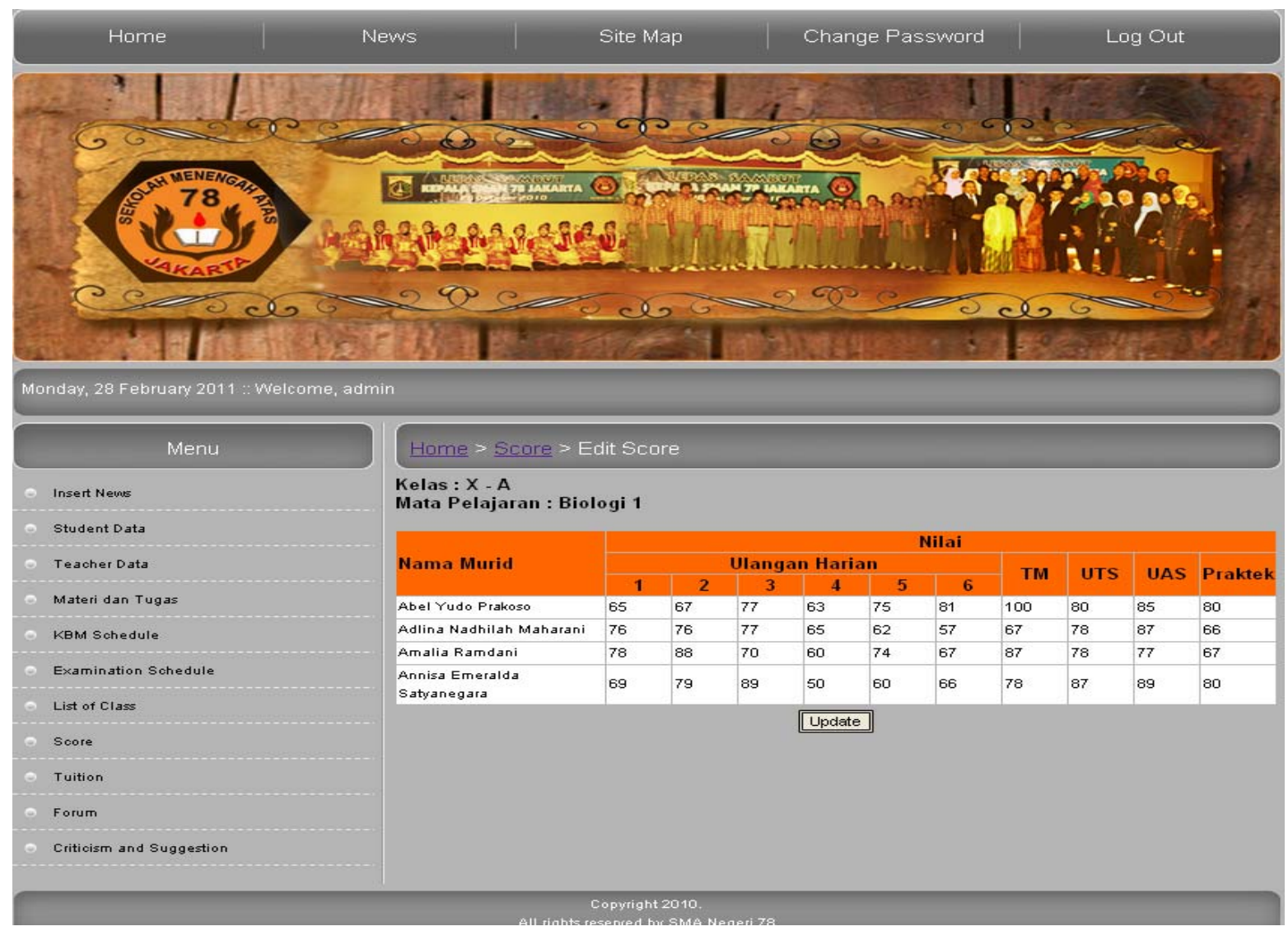

Gambar 18. Halaman admin - Score - Option - Edit Score.

Tuition, digunakan untuk melihat data iuran siswa, memasukkan data iuran siswa dan memperbaharui data iuran siswa berdasarkan kelas dan bulan. Forum, untuk melihat topik-topik diskusi forum tiap kelas dan dapat menghapus topik tersebut. Criticism and Suggestion, untuk melihat daftar aspirasi yang berupa saran, kritik dan pertanyaan dari guru dan siswa. Admin juga dapat merespon aspirasi tersebut. Untuk keluar dari menu-menu ini, admin dapat mengklik Log Out.

\section{PENUTUP}

Pada kenyataannya sistem informasi manajemen sekolah telah menjadi suatu kebutuhan bagi sekolah-sekolah. Untuk aplikasi, proses dan data pendukung dapat disesuaikan dengan kebutuhan masing-masing sekolah yang bersangkutan. Dari analisis dan perancangan yang dilakukan, dapat disimpulkan bahwa: (1) sistem informasi manajemen sekolah ini mempermudah pihak sekolah dengan segala hal yang mereka inginkan yang berkaitan dengan data administrasi, data guru, data siswa, data iuran siswa dan sebagainya; (2) sistem informasi manajemen sekolah dapat menghilangkan hambatan jarak dan waktu karena dapat diakses dimana saja selama 24 jam sehingga membuat komunikasi antar elemen sekolah berjalan lebih lancer; (3) siswa dapat mengakses nilai mereka dari mana saja dan dimana saja; (4) siswa dan guru dapat memberikan masukan dan pertanyaan bagi sekolahnya yang bisa ditanggapi secara langsung oleh pihak yang berwenang; (5) sistem ini juga menyediakan menu materi pelajaran dan tugas yang bisa diunduh oleh siswa, sehingga memudahkan siswa dalam memperoleh materi tambahan dari guru yang bersangkutan. Siswa juga dapat mengumpulkan tugasnya melalui menu upload tugas; (6) terdapat pula menu berita yang berisi informasi terbaru mengenai 
berita-berita ataupun kegiatan di sekolah; (7) adanya forum yang memungkinkan interaksi siswa dan guru diluar jam pelajaran sekolah dan memudahkan proses belajar mengajar; (8) aplikasi ini bersifat informatif dan mudah digunakan karena sederhana dalam menggunakan fitur-fitur yang ada di dalamnya; (9) aplikasi ini telah memberikan nuansa baru dalam proses pembelajaran yang ada di SMA Negeri 78 Jakarta.

\section{DAFTAR PUSTAKA}

Connolly, T. M. \& Begg, C.E. (2005). Database Systems: A Practical Approach to Design, Implementation, and Management, ( $4^{\text {th }}$ ed.). New Jersey: Addison-Wesley.

Hoffer, Jeffrey A., Mary B. Prescott, Fred R. McFadden. (2005). Modern Database Management,Seventh Edition. New Jersey: Prentice Hall.

Post, Gerald V. (2005). Database Management Systems, (3 ${ }^{\text {rd }}$ edition). New York: McGraw-Hill.

Turban, Efraim, Rainer, R.Kelly, Potter, Richard E. (2005). Introduction to Information Technology, $\left(3^{\text {rd }}\right.$ ed.). New York: John Wiley \& Sons.

Waller, Vaughan. (2001). A Definition for E-learning in Newsletter of Open and Distance Learning Quality Control. Diakses 12 Maret 2011 dari http://www.odlqc.org.uk/odlqc/n19-e.html.

Whitten, J.L., Bentley, L.D. \& Dittman, K.C. (2004). System Analysis and Design Method. (6 ${ }^{\text {th }}$ ed.). New York: McGraw-Hill. 